\title{
Analyzing the Results of Accounting Evaluation Methods Through Practical Applications
}

\author{
Ibrahim Mert \\ Business Administration, Istanbul Aydin University, Istanbul, Turkey \\ Email address: \\ ibrahimm1508@yahoo.com, ibrahimm@aydin.edu.tr

\section{To cite this article:} \\ Ibrahim Mert. Analyzing the Results of Accounting Evaluation Methods Through Practical Applications. European Business \& Management. \\ Vol. 6, No. 4, 2020, pp. 95-104. doi: 10.11648/j.ebm.20200604.14
}

Received: July 6, 2020; Accepted: July 25, 2020; Published: August 20, 2020

\begin{abstract}
Even though different types of accounting evaluation approaches have been discussed in this article, mainly the income-based approach to business evaluation, asset-based approach to business evaluation and practical case evaluation have been analyzed. This article presents the principles of assessment of accounting items as active, external sources and equity and how financial performance is reflected. An important detail in this part of the project is the method of approach in assessing the direct reference to the main base for determining the elements of external sources and equity. In this analysis I have left the rules in the International Accounting Standard Board (IASBF) Framework, which provides tax assessment: historical cost, current cost, realizable value (settlement) and the present value as far as external sources are concerned such as stocks, bonds, and others. Fair value should be added as the basis for evaluation, even if not expressly provided for the general, is often used to IFRS as a basis for evaluating several external sources. I believe that this assessment is not at a crossroads about the theoretical and practical evaluation of most elements of external sources at fair value, including all sources from ordinary activities, which are recognized in the accounts at fair value.
\end{abstract}

Keywords: Evaluation, Revaluation, Historical Value, Fair Value, Financial Statements, IFRS, Accounting Regulation

\section{Introduction}

The necessity of assessment or evaluation is coming from the abnormality, meaning there are some results they are not matching to the company's current situation. For example, if there were no economic crises or high inflationary periods in a specific country, the evaluation of an asset may not be necessary. If there is an extraordinary change in "the general level of prices", we cannot see the correct picture of the company when we look at its balance sheet. That means even though the balance sheet should reflect the position of the company at that moment, this would not be possible.

Even though there are many other factors to establish the revaluation of the fixed assets of an entity, especially in the countries where "continuous high inflation" exists, reassessment would be very important. In these kinds of countries, other than international accounting standards, governments are taking additional measures in order to decrease the effects of the movements of prices general level.

Even though economic crises have a shock effect on economies, the effect of "continuous high inflation" may damage the economic environment more.

This paper is trying to observe that what the effects of the latest national changes on the way to be closer to the international approaches or not. After having the adapted regulations, how closer the applications of fixed asset evaluation to international practices. This analysis has been provided on the further chapters with numerical and wordy explanations.

\section{The Income-Based Approach to Business Evaluation}

The income-based methods are used for valuing the business as a continuing entity. The analysis is based on the ability of a business to generate income and the degree of risk assumed by the owners. It can be observed that this method of evaluation is mostly used especially for the businesses that are not asset-based.

Two variations of the basic capitalization are commonly applied. Capitalization of future income streams based on the 
accounting cash flows of the firm is considered appropriate where a firm is managed by non-owner professional managers. Capitalization of discretionary cash flows, adjusted for all personal benefits provided by the business, in addition to the accounting cash flows generated by the business, is considered more appropriate in the case of owner-managers [8].

The following factors are commonly used by an appraiser to determine an appropriate "capitalization rate", which is used to compute the market value of the business based on the income or cash flows of the business. As it was modeled that assets with large upsides are overpriced. Assets with large downsides are underpriced [1].

There have been three approaches to valuing a commercial operation - market, income as good as an asset. These easily cover the income approach.

\subsection{Types of Earnings}

There have been many sorts of gain used in commercial operation gratefulness methods. Here have been many usual ones with short explanations. It is intensely critical to work a scolding sort of gain for a comparison method.

Earnings before taxes (pre-tax earnings) - Many gratefulness methods work pre-tax earnings.

Earnings before interest, taxes, debasement \& amortization (EBITDA) - EBITDA is a tighten estimation of money upsurge since it adds behind a non-cash loss of debasement as good as amortization. A mixed of EBITDA is a usual gratefulness formula [3].

Cash flow - There have been many sorts of money flow. Cash upsurge is a deliberate some-more pristine form of gain as good as is mostly elite for valuations.

Seller's optional gain (SOG) - For owner-operated companies, SOG, is an elite gain for gratefulness since it represents a sum gain access to an owner. SOG starts with EBITDA afterward add behind the owner's remuneration as good as benefits.

For an association which has vacillating or comparatively fast earnings, a 3 to 5 year normal will many suitable simulate an earning genius of a company [13]. A weighted normal can be used to give a larger weight to specific years. If the gain has been consistently flourishing or falling, a formula from a new year might be an improved choice.

\subsection{Multiple of Seller's Discretionary Earnings (SOG)}

This process relates a mixed to an SOG of an association to establish a value. The mixed can come from multiform sources.

This process is many suitable matched to an association where income as good as perquisites of an owners paint a poignant apportionment of sum benefits generated by a company, as good as an owner typically runs day-to-day operations. Buyers as good as sellers of small companies lend towards to cruise in conditions of their intensity personal remuneration rather than commercial operation profits [6]. They demeanor during a sum optional gain to see if it is enough to lift a debt make up required to buy as good as work a company, as good as yield them with competitive compensation.

\subsection{Capitalized Cash Flow}

The capitalized money upsurge (CMU) process converts a money upsurge of an association into a worth regulating a capitalization rate. The money upsurge is widely separated by a capitalization rate. The capitalization rate reflects an increased rate of lapse, as described in Part 3.

This process functions well when an association has a story of stable, growing, or poignant money flow; as good as minimal discernible assets. It reflects a worth of an association from the view of a financier or absentee owner.

\section{An Asset-Based Approach to Business Evaluation}

It is clear that are there are plenty of methods to define the value of a company. An asset-based evaluation system is one of the business evaluations [8]. The other methods are the income approached evaluation, and the market approached evaluation.

The asset-based approach of business evaluation works according to the substitution assumptions. In the structure of this approach, it is expected that a rational investor can invest in the assets, which are in their benefit. Another word, the capital owners may spend their economic values for an asset, which they think has the correct price.

\subsection{Adjusted Net Book Value}

The adjusted net book value approach is one of the assetbased approaches for business evaluation. It functions differently than the income-based approach in the way that Adjusted Net Book Value is considered as an objective method. Here, the purchasing cost of the asset is used, and if there is an understanding of excluding a depreciation expense, it is just applied. The important thing for an asset is to convert its value to the fair market price whenever it is possible [15]. Generally, this conversion is, sometimes, not possible, for example, for goodwill because these are not considered as assets.

\subsection{Performing Adjusted Net Book Value}

Adjusted Net Book Value is mostly applied in the cases when a company is selling its assets to pay off its debts. In the cases of liquidation, this method is also utilized.

To use the Adjusted Net Book Value, the company's income should be less than or equal to its assets.

Business Valuation requires an understanding and application of appropriate techniques. Revenue Rulings issued by the IRS describe the factors and approaches to be considered while valuing businesses. Three main approaches used in business valuation are Income, Asset, and Market Approaches [9]. Within each of the approaches, the appraiser 
has to select specific methods appropriate for the purpose of valuation. A brief description of these approaches follows.

Asset-based methods focus on the value of a firm's assets rather than the expected cash flows. This approach is considered appropriate when a business is asset-intensive. Retail businesses and established manufacturing companies without substantial growth prospects fall into this category [16]. This process considers the following factors to calculate the market value of the business.

* FMV/FA (fixed asset's fair market value) - The price is to buy an asset from a free market, as distinct from the book value of the asset. A qualified machinery appraiser, familiar with the industry, is usually retained to provide these values.

* LI (Leasehold improvements) - These are the physical improvements on property which are considered as part of the property doesn't matter to renew the lease, or sell it.

* (I) Inventory - Inventory's wholesale value is appraised.

The sum of all these assets is subtracted from the outstanding liabilities of the company.

\subsection{Market Based or Multiplier Valuation}

This approach values a business by using an "industry average" rule of thumb multiplier. The average industry number is usually based on the ratio of price paid and revenue, profit, or asset values for comparable businesses in recent transactions. This is a rather ad-hoc approach as it tends to disregard the differences between businesses in the same industry. It is also difficult to identify exact comparables for the business being valued. At best, this approach is useful as a sanity check for valuations derived from income or asset-based approaches.

\section{Practical Case Evaluation}

It is not important if a company performs an evaluation by itself for its own assets, or utilizes a professional appraiser for this process. The important point is to find out the main method of evaluation to conclude the value of the company to buy. If a professional business appraiser to be chosen for evaluation, this person would utilize some suitable methodologies and own experiences to calculate the value of a company. There are three main evaluation approaches for the evaluation process; Asset Valuation Approach, Comparable Worth Approach, and Financial Performance Approach.

\subsection{The Asset Valuation Method}

If the portion of fixed assets utilizes a big part of the value of a company, then, an appraiser may take a specific model of evaluation method to get the price of the entity. The principal for clarification of the value of the assets is that buyers would pay only as much as the value of a similar company that can be obtained in a fair market [11]. According to this clear framework, the appraiser would decide to choose the proper method to value the targeted company or asset by figuring out the "cost of reproducing" the same asset by utilizing the same production inputs, namely, workmanship, materials, and overheads. The production inputs would be the same, but according to the current market prices. Or, the appraiser may take another way such as the "cost of replacement", meaning, of acquiring a similar asset on the base of the present price. Of course, the appraiser should also pay attention to the reception time for the new assets to be put in the place of the previous one up to being in function [18].

The method of asset valuation takes into account for each asset of the company, meaning tangible and intangible assets. The most important point in this deal is to get the fair value of the targeted assets. All assets such as buildings, lands, equipment, machinery, vehicles, furniture, and all inventories must be evaluated by the appraiser [12]. All intangibles such as patents, trademarks, clients, company organization, market share, etc., as goodwill, also should be appraised. Of course, convincing the buyer about the values of intangible assets would be more difficult than that of tangible assets since the second ones are clearer to see and observe. Intangible assets have economic value to the extent that their use is aligned with the implementation of business strategies and related to the priorities set by the overall strategy of the company [14].

It can be said that supplying the appraiser with detailed information about the intangible assets would be in favor of the seller of the company. If the value of the goodwill of the company is based on more specific or more understandable intangibles, this may set a higher value for a company. Instead of presenting under a whole figure, if these types of intangibles are presented with a sub-detailed, it would create a clearer picture of the goodwill. According to this perspective, patents, licenses, contracts, and even client structure and market share should be specifically and detailed. Nowadays, intangible assets and the ways of their use are more important than the category of so-called material substances [11].

\subsection{The Comparable Worth Approach}

The logic of the Comparable Worth Approach defines the value of the evaluated company, by comparison, the similar ones in the market. According to this approach, the appraiser analysis the companies which are in the same or similar industry, producing the same or similar types of products or service, in the same or similar location, and period time [5]. The expectation from this appraising is obvious that the buyer would not pay any more value for this company than the value of the similar ones in the fair market. For this reason, the appraiser person should pay sensitive attention while trying to find out in the fair market as similar conditions as that targeted company has. If there are no the same or similar conditions in the market to make the comparison, then the appraiser should create a logical and understandable way of comparisons by also utilizing the previous experiences, studies, and techniques. Whenever the appraiser reaches a rough calculation, then there may be specific and detailed additions, subtractions, corrections, etc. 


\subsection{Financial Performance Methods}

One of the most used methods of evaluation of buyingselling small-medium types of entities is Financial Performance Methods. These methods pay attention not only to the historical success of the company but also to future expectations. Financial Performance Methods focus on mainly the calculations of Internal Rate of Return (IRR), Net Present Value (NPV), and Return on Investment (ROA).

Net Present Value can be considered as the most used formula for appraisers to calculate the financial performance of companies in acquiring stages. NPV is the difference between the benefit and cost of the offered amount. If the benefit is more than the cost, the buying-selling transaction would be in the benefit of the buyer. Or, if the benefit is less than the cost, the transaction would be at the disadvantage of the buyer. If there is no difference, the benefit and cost are equal to each other, and there is no favor or disadvantage for the buyer or seller.

Internal Rate of Return formula is used to reach the discount rate, which is the difference between the proposed price and the anticipated profit from other opportunities. For example, the buyer should calculate that instead of using the capital by purchasing the proposed assets, it can be deposited to a bank and according to this alternative, to reach the same level of benefit what should be the interest rate that the bank should propose. In this process, the appraiser follows the following two stages: One, after calculating the IRR, the appraiser compares the result of IRR, expected Rate of Return. If the IRR is more than the expected rate of return, the transaction should be accepted. If the IRR result is less than the expected rate of return, then the transaction shouldn't be accepted. In case they are equal, the decision would be indifferent to shareholders [17].

Return on Investment Ratio formula is utilized if there are special situations in the decision process of buying a company. In this calculation, previous years' earnings are summed, and the result of the sum is compared with the total of long term debts and equity of the company.

\subsection{Application Process}

An appraiser should perform the evaluation process by utilizing different calculations, factors, and points to produce a respectful appraising report. By going this way, the appraising report would have more respect and trust from the parties. As an instance, if the appraising process ends with the result range from $\$ 5.0$ million to $\$ 4.5$ million, in that case an asset that has a value of $\$ 3.5$ million can be indifferent if the appraiser considers that the value of the asset is not fair for prorating to the whole value of the company.

It can be underlined that a respectful evaluation process has lots of difficulties and considerable time for efforts. Even though a proper calculation is more valuable, sometimes parties may not request such detailed calculations. One of the simple ways of calculations is called industry multipliers. For example, as an easy methodology, in a specific industry, the price of a company can be seven times of that company's annual turnover.

\subsection{Analyzing the Final Evaluation Report}

At the end of the appraisal calculation, the appraisers prepare a final evaluation report to submit to the parties [16]. The essential part of this report, of course, is the range of the values of the company that is in buying-selling transactions. Whenever the appraiser presents the final appraising report, the parties would evaluate the written range of value of the company. If the parties consider that the range is fair, they may continue to the process to finalize the transaction. It is also worth to conclude that whether the impairment-only approach provides more useful information to investors relative to amortization remains unanswered [4].

\section{Study of Methods of Evaluation by Comparative Analyses}

\subsection{Corrected Net Asset Method}

An efficient approach is based on the principle substitution, which says that an asset is worth more than the cost replacement of all its components.

This means that an investor will pay more for a company more than it would cost to create an entity with an equivalent utility. From a technical standpoint, the evaluator must estimate the values of each asset of the company and also the corresponding value of each element of liabilities, and the adjustments should be reflected in the related accounts of accounting.

In this approach, based mainly on the balance sheet values expressing the cost are replaced by balance sheet reflecting all assets, tangible and intangible assets and all liabilities, at their current market value or adequate if the net asset method corrected (ANC).

It is obvious that the outcome of the method employed in this approach should not be the only result when evaluating operating companies and will operate for a foreseeable future period.

\subsection{Valuation of Property (Case Study)}

Polar Corp. presents the following situation at 31.12.2015 accounting of assets and liabilities.

Table 1. Accounts of assets and liabilities of Polar Corp.

\begin{tabular}{ll}
\hline Specification & Accounting Values (USD) \\
\hline A. ASSETS & \\
I. Fixed Assets & \\
1. Intangible & 62,500 \\
2. Land & 267,750 \\
3. Net asset value & $2,682,000$ \\
4. Asset in progress & 0 \\
5. Financial assets & 122,500 \\
TOTAL I (1-5) & $3,134,750$ \\
II. Current Assets & \\
1. Raw Materials & 184,500 \\
2. Finished products & 634,250 \\
3. Production in process & 0 \\
\hline
\end{tabular}




\begin{tabular}{ll}
\hline Specification & Accounting Values (USD) \\
\hline 4. Animals & 30,750 \\
5. Goods and packaging & 253,000 \\
6. Accruals and similar & 0 \\
7. Premium regarding reimbursement & 0 \\
obligations & 49,000 \\
8. Cash and banks & 0 \\
9. Investment securities & $1,985,750$ \\
10. Others & $3,137,250$ \\
TOTAL II (1-10) & $6,272,000$ \\
TOTAL A=I II & 0 \\
B. LIABILITIES & $1,591,500$ \\
1. Loans and other payables & 667,250 \\
2. Suppliers & 75,000 \\
3. Creditors & 87,250 \\
4. Dividends payable & 627,250 \\
5. Other liabilities & 0 \\
6. Accruals & $3,048,250$ \\
TOTAL B (1-6) & $3,223,750$ \\
NET ASSETS=A - B & \\
\hline
\end{tabular}

After diagnostic analysis is retained and given a series of information, below process is continued;

1) Intangible assets recorded in the balance $(\$ 62,500$ net) of Polar Corp. represents a program management information acquired two years ago the price of $\$ 125,000$ and is no longer used on evaluation;

2) The company has a lease for a space product sales presentation with a surface of $100 \mathrm{sqm}$. The analysis revealed that the rent is $\$ 125$ bond while the monthly market rent is $\$ 175$ / sqm per month. The remainder of the contract two years and the rent is the risk-free rate of return to reporting date is $5 \%$;

3 ) The book value of the land is from $\$ 267,750$ last revaluation according to 2004; the land area is 3,000 square meters, and the analysis of comparable transactions result that prices are trading at about $\$ 500,000$ / sqm.

4) Fixed assets have a book value of $\$ 2,682,000$ and include:

* A manufacturing unit in a built-up area of 3,000 square meters commissioning date of June 2002. Value at commissioning was $\$ 500,000$, and the value remaining in the accounts (after revaluation as 2017) is $\$ 1,125,000$. Price index construction from June 2015 to June 2014 is 20,5, and during normal use of this asset is 50 years;

* A comprehensive line of processing one with a yield PWK 1,500 unit/24 h, acquired in 2016 to a price of $\$ 625,000$ and has a remaining value accounting after revaluation of $\$ 712,500$. Based on information from manufacturers, the cost of new lines, PWK 2 is manufacturing $\$ 1,050,000$, but with a yield of $2.000 \mathrm{~h}$. The normal duration of unit/24 Use of such equipment is 25 years. The technical analysis showed that the capacity factor cost of this equipment is 0.7 .

* Other fixed assets are recorded net accounting for $\$ 844,500$ and this reflects the value their market;

* Financial Assets are units in a company went into bankruptcy (Arctic Corp.);

1) Stocks include a batch of finished products that were refused by the recipient as a result of qualitative deficiencies. The issue is by negotiating with another client to sell these stocks with a reduction of $\$ 125,000$. For these stocks there were no provisions;

2) Inventories of goods have been stored improperly and therefore, and there was a physical impairment of a number 10 pallets whose book value was $\$ 187,500$;

3 ) The category of claims is included in accounts receivables of Arctic Corp. amounting to $\$ 112,500$, which practically cannot be recovered.

Based on data analysis was done to assess assets as follows:

\subsubsection{Evaluation of Intangible Assets}

1. a) As a result of the management software has no utility and it can not be exploited market showed that the assessed value of that asset intangible is zero and so it is necessary to adjust the value accounting of fixed assets minus $\$ 62,500$.

1. b) The company has an advantage of contract rent (separate intangible asset, recorded in the balance sheet) being valued by capitalizing on cost savings as follows:

1) Annual cost savings

100 sqm $x$ ( $\$ 175$ / sqm per month - \$125/sqm) per month $\mathrm{x}$ 12 months $=\$ 60,000 /$ year

2) Discount factor for a rate of $5 \%$ and a duration 2 years

$\mathrm{f}(5 \%, 2$ years $)=1 /(1+0.05) \times 1+1 /(1+0.05) \times 2=1.859$

3) The advantage of the agreement

$$
\$ 60,000 / \text { year } \times 1.859=\$ 111,500
$$

In these circumstances, it is necessary to adjust the carrying value with the addition of fixed assets $\$ 111,500$.

\subsubsection{Land Evaluation}

This was done by comparison. Based on data analysis, industrial land with comparable transactions revealed that the market value of the land is:

$$
3,000 \text { sqm. } x \$ 125 / \text { sqm. }=\$ 375,000
$$

It is, therefore, necessary to adjust the carrying amount of land plus with $\$ 107,250$.

\subsubsection{Building Assessment}

For the assessment, the method was used manufacturing hall net replacement cost.

a) Gross replacement cost is based on the indices and the gross replacement cost will be:

$$
2.000 \mathrm{sqm} . \mathrm{x} \$ 4,850 / \mathrm{sqm} .=\$ 9,700,000
$$

b) Estimated depreciation (excluding depreciation physical) is based on the ratio of lifetime consumption and normal life.

$$
\begin{aligned}
& \text { Physical Impairment }=11 \text { years } / 50 \text { years }=22 \% \text { that } \\
& \qquad \$ 9,700,000 \times 0.22=\$ 2,134,000
\end{aligned}
$$

c) Dhe replacement cost, replacement cost net=gross value - depreciation 


$$
\$ 9,700,000-\$ 2,1434,000=\$ 7,566,000
$$

It is, therefore, necessary to adjust the carrying amount of buildings plus $\$ 6,441,000$.

\subsubsection{Evaluation of Complex line (ECL)}

It uses the net replacement cost method.

a) Replacement cost is based on the relationship of gross cost yield:

Gross replacement cost ECL ECL 2 x 1=Cost (Capacity ECL $1 /$ Capacity ECL 1 )

factor cost- capacity

$$
\begin{gathered}
\$ 1,050,000 \times(375,000 / 500,000) 0,7=\$ 1,050,000 \times \\
0.818=\$ 858,900
\end{gathered}
$$

b) Estimated depreciation (excluding depreciation physical) is based on the ratio of lifetime consumption and normal life:

Physical Impairment $=10$ years $/ 25$ years $=40 \%$ respectively:

$$
\$ 859,000 \times 0.40=\$ 343,600
$$

c) The replacement cost replacement cost net=gross depreciation

$$
859,000-343,500=\$ 515,500
$$

It is therefore necessary to adjust the value of equipment less $\$ 172,000$.

\subsubsection{Assessment of Financial Securities}

As a result of the Polar Corp. procedure came into Arctic Corp. bankruptcy and the shareholders cannot recover anything from the invested capital adjustment is necessary for the carrying amount of minus $\$ 122,500$.

\subsubsection{Measurement of Inventories}

Due to quality problems and finished products, the physical depreciation of stocks of goods is required adjustment $\$ 312,500$ of stock minus (minus $\$ 125,000$ finished product goods minus $\$ 187,500$ ).

\subsubsection{Debt Rating}

Failure to collect the Arctic Corp. client the bill $\$ 112,500$ implies a negative adjustment in the value accounts receivable.

Adjusted net asset method (ANAM) is completed with achieving a table that summarizes the carrying amounts are taken, and that appropriate adjustments of assessed values of

\begin{tabular}{|c|c|c|c|c|}
\hline Specification & Accounting Values & Adjustments & Corrected Values & Explanations \\
\hline \multicolumn{5}{|l|}{ A. ASSETS } \\
\hline \multicolumn{5}{|l|}{ I. Fixed Assets } \\
\hline 1. Intangible & 62,500 & 49000 & 111,500 & $1 \mathrm{a}$ and $1 \mathrm{~b}$ \\
\hline 2. Land & 267,750 & 107250 & 375,000 & 2 \\
\hline 3. Net asset value & $2,682,000$ & $6,244,000$ & $8,926,000$ & 3 and 4 \\
\hline 4. Asset in progress & 0 & 0 & 0 & \\
\hline 5. Financial assets & 122,500 & -122500 & 0 & 5 \\
\hline TOTAL I (1-5) & $3,134,750$ & $6,277,750$ & $9,412,500$ & \\
\hline II. Current Assets & & 0 & 0 & \\
\hline 1. Raw Materials & 184,500 & 0 & 184,500 & 0 \\
\hline 2. Finished products & 634,250 & -125000 & 509,250 & 6 \\
\hline 3. Production in process & 0 & 0 & 0 & \\
\hline 4. Animals & 30,750 & 0 & 30,750 & \\
\hline 5. Goods and packaging materials & 253,000 & -187500 & 65,500 & \\
\hline 6. Accruals and similar & 0 & 0 & 0 & \\
\hline 7. Premium regarding reimbursement obligations & 0 & 0 & 0 & \\
\hline 8. Cash and banks & 49,000 & 0 & 49,000 & \\
\hline 9. Investment securities & 0 & 0 & 0 & \\
\hline 10. Others & $1,985,750$ & -112500 & $1,873,250$ & 7 \\
\hline TOTAL II (1-10) & $3,137,250$ & $-425,000$ & $2,712,250$ & \\
\hline TOTAL A=I + II & $6,272,000$ & $5,852,750$ & $12,124,750$ & \\
\hline B. LIABILITIES & 0 & & 0 & \\
\hline 1. Loans and other payables & $1,591,500$ & 0 & $1,591,500$ & \\
\hline 2. Suppliers & 667,250 & 0 & 667,250 & \\
\hline 3. Creditors & 75,000 & 0 & 75,000 & \\
\hline 4. Dividends payable & 87,250 & 0 & 87,250 & \\
\hline 5. Other liabilities & 627,250 & 0 & 627,250 & \\
\hline 6. Accruals & 0 & 0 & 0 & \\
\hline TOTAL B (1-6) & $3,048,250$ & 0 & $3,048,250$ & \\
\hline NET ASSETS $=A-B$ & $3,223,750$ & $5,852,750$ & $9,076,500$ & \\
\hline
\end{tabular}
assets and company debt.

If Polar Corp. adjusted net assets are $\$ 9,076,500$ compared with net assets accounting for $\$ 3,223,750$.

Table 2. Determination of corrected net asset Polar Corp. 
Each of the adjustments assumed in the third column of the Table presented includes a note (explanation) that connects with the valuation method applied in evaluating each of the elements heritage.

\subsection{The Income Capitalization Method (Profit)}

The income approach is based on the principle substitution in the sense that an investor would prefer investment in the same risk provides a higher return. The identification and quantification of the company's risks (opportunities and threats) must be the basis for the risk-appropriate evaluation of a company [7]. The principle anticipating and contribution is essential to the methods listed in the income-based approach.

Polar Corp. presents the following income statement and expenditure for 2015, considered as an evaluation year representative:

Table 3. Statement of revenue and expenditure Polar Corp. (2015) (Million).

\begin{tabular}{ll}
\hline SPECIFICATIONS & BOOK VALUES \\
\hline A. INCOME & \\
1. Turnover & $7,875,000$ \\
2. Income from production sold & 375,000 \\
3. Other operating income & 55250 \\
4. Financial income & 12500 \\
5. Extraordinary income & 82250 \\
TOTAL INCOME (1-5) & $8,400,000$ \\
B. EXPENSES & \\
1. Raw materials & $2,756,250$ \\
2. Salaries & $2,205,000$ \\
3. Outsourcing services & 195000 \\
4. Taxes & 37500 \\
5. Depreciation & 253,000 \\
6. Financial expenses & 187500 \\
7. Extraordinary expenses & 125000 \\
TOTAL EXPENSES (1-7) & $5,759,250$ \\
GROSS PROFIT & $2,640,750$ \\
Income tax & 739,410 \\
NET PROFIT & $1,901,340$ \\
\hline
\end{tabular}

Since this diagnosis, I noticed the following conclusions:

1) Turnover of 2002 included the income of $\$ 125,000$ from the rental of equipment to a customer Mexico, which then has liquidated the business. This was a single transaction in that market and is not expected future sales in this market (equipment continues to be used in operational activities Polar Corp.)

2) Have registered and income from rent of space owned No. 22 Main Street for $\$ 55,250$. This property is not used in production or Polar Corp. Expenses of this asset depreciation of $\$ 12,000$ per year and tax property of 24 million. Market value (net achievement) of this property has been estimated by compared to $\$ 331,500$; The company has made exceptional income $\$ 82,250$ from the sale of means of transport which value remaining in the accounts was $\$ 50,000$;

3) material costs in 2015 were affected by the fact that one provider has temporarily stopped work, which made the provision to be made of import cost about $\$ 175,000$ due to higher custom taxes [19];

4) Average wage costs in the enterprise workers are about $\$ 21,250$ per year, and since 2016, 10 workers were retired without being a need for further employment;

5) Financial costs include an amount of $\$ 187,500$ representing interest on a long term credit $\$ 1,591,500$;

6) Exceptional costs include fines of $\$ 75,000$ and the remaining value of $\$ 50,000$ of transportation means sold in 2015;

7) Income tax on the ratio is $25 \%$ gross result.

Based on these data were considered the following adjustments:

1. It will adjust revenue by subtracting $\$ 125,000$ due to reproducible record income in the future.

2. It will adjust revenue by subtracting $\$ 55,250$ due to the record for an asset for income from other revenues.

3. It will adjust the cost of non-operational assets:

a) $\$ 12,000$ depreciation minus

b) $\$ 6,000$ minus taxes

4. Material costs will be adjusted as minus $\$ 175,000$ since the supply will continue achieved from domestic suppliers.

5 . As a result of reducing the number of employees, the cost of salaries will be adjusted to minus $\$ 212,500$.

6 . Because we will first be paid the amount of capital invested, we will adjust the interest costs (minus \$187,500) that the loans will be deducted from the capital to determine the market value equity.

7. It will adjust the income and extraordinary expenses with the full book value (minus $\$ 82,250$ revenue windfalls and minus \$125,000 exceptional expenses).

And the income capitalization method evaluation is complete is based on synthetic table values are taken accounting adjustments for the items of income/expense and that their adjusted values in this situation each from adjustments assumed in the third column of the table will include a note explaining the adjustment and argument.

Table 4. Determination of annual net profit reproducibility of Polar Corp.

\begin{tabular}{|c|c|c|c|c|}
\hline SPECIFICATIONS & Accounting Values & Adjustments & Corrected Values & Explanations \\
\hline \multicolumn{5}{|l|}{ A. INCOME } \\
\hline 1. Income from Production sold & $9,625,000$ & 0 & $9,625,000$ & \\
\hline 2. Income from renting the equipment & 125,000 & $-125,000$ & 0 & 1 \\
\hline 3. Income from renting the buildings & 55,250 & $-55,250$ & 0 & 2 \\
\hline 4. Financial income & 0 & 0 & 0 & \\
\hline 5. Extraordinary income & 82,250 & $-82,250$ & 0 & 7 \\
\hline TOTAL INCOME (1-5) & $9,887,500$ & $-262,500$ & $9,625,000$ & \\
\hline
\end{tabular}




\begin{tabular}{|c|c|c|c|c|}
\hline SPECIFICATIONS & Accounting Values & Adjustments & Corrected Values & Explanations \\
\hline \multicolumn{5}{|l|}{ B. EXPENSES } \\
\hline 1. Raw materials & $3,368,750$ & $-175,000$ & $3,193,750$ & 4 \\
\hline 2. Salaries & $2,695,000$ & $-212,500$ & $2,482,500$ & 5 \\
\hline 3. Outsourcing services & 195,000 & 0 & 195,000 & \\
\hline 4. Taxes and fees & 37,500 & $-6,000$ & 31,500 & 3 \\
\hline 5. Depreciation & 253,000 & $-12,000$ & 241,000 & 3 \\
\hline 6. Financial expenses & 187,500 & $-187,500$ & 0 & 6 \\
\hline 7. Extraordinary expenses & 125,000 & $-125,000$ & 0 & 7 \\
\hline TOTAL EXPENSES (1-7) & $6,861,750$ & $-718,000$ & $6,143,750$ & \\
\hline GROSS PROFIT & $3,025,750$ & 455,500 & $3,481,250$ & \\
\hline Income tax & 847,210 & 127,540 & 974,750 & \\
\hline NET PROFIT & $2,178,540$ & 327,960 & $2,506,500$ & \\
\hline
\end{tabular}

To estimate the appropriate cost of capital we had the following:

$$
\text { WACC }=\text { KPR ccpr } \mathrm{x} \% \mathrm{x} \% \mathrm{~d}+\mathrm{D} \times(1-\mathrm{ci})
$$

1) Cost of Equity=Net profit (adjusted): Capital own $($ corrected net assets $)=\$ 2,611,000 / \$ 9,076,500=28.8 \%$

2) $\mathrm{Cost}=$ cost of borrowed capital with interest: Interestbearing loans $=\$ 187,500 / 1,591.500=11.8 \%$

3 ) The average cost of capital (WACC) Relationship is determined based on

where:

1) $\mathrm{WACC}=$ weighted average cost $\mathrm{KPR}=\bullet \%$ share in equity capital invested

2) $d=$ interest rate

3) $\% D=$ weight of debt in total capital invested

4) $\mathrm{ci}=$ corporate tax rate

Table 5. Determination of weighted average cost of capital Polar Corp.

\begin{tabular}{lllll}
\hline SPECIFICATIONS & Values & \% & Cost of capital & Heavy average cost \\
\hline Equity & $\$ 9,151,500$ & $85.20 \%$ & 28.8 & $\mathrm{x}$ \\
Loans & $1,591,500$ & $14.80 \%$ & 11.8 & $\mathrm{x}$ \\
Total & $\$ 10,743,000$ & & & $25.80 \%$ \\
\hline
\end{tabular}

It follows a weighted average cost (discount rate) equal to $25.8 \%$.

Considering a growth rate $\mathrm{g}=5 \%$ will result in the following estimated income capitalization method

$$
\begin{gathered}
\mathrm{V}=\mathrm{PN} /(\mathrm{a}-\mathrm{g})+\mathrm{NVA}=\$ 2,611,000(28.8 \%-5 \%)+ \\
\$ 336,500=\$ 621,418+\$ 336,000=\$ 957,418 .
\end{gathered}
$$

Note: $\mathrm{NVA}=$ net value of assets outside the operating performance (when the assets located in Main Street has been estimated at $\$ 331,500)$.

Previously estimated value is the amount of capital invested. If we infer from this long-term credit get

$$
\begin{gathered}
\mathrm{V}=\text { capital invested }- \text { Credits }=\$ 10,970,250- \\
\$ 1,591,500=\$ 9,378,750 .
\end{gathered}
$$

\subsection{Update Cash Flow Method (UCFM)}

The method is based on updating the full benefits projected economic (cash flow or other similar variables) the enterprise using a discount rate representing the cost capital for that investment. From a technical standpoint is one of the most complex methods of assessment, based on her relatively detailed forecasts of future business activity. The final method involves the construction of a synthetic table that takes detailed information on projections made by the assessor.
To use this method at Polar Corp. Consider the following assumptions:

1) Dynamic turnover is estimated in the following table;

2) Estimated net profit stabilized at $25.5 \%$ of sales business (have been taken into account interest costs);

3) Working capital requirement is estimated as stable as relative size (34\% of turnover)

4) Loan repayment will be made according to contract Credit 2015-2019.

5) Investments are estimated at $\$ 375,000$ / year, and depreciation is considered stable at $\$ 241,000$ / year.

\subsection{Assessment of the Applicability of Evaluation Methods}

Setting the evaluator's opinion

Considering that there are three axes major undertaking assessment [2]:

1) Return;

2) Net asset (property);

3) Turnover.

This classification provides possible areas of research and taking their views into account in some discipline and development profession, especially in recent years (particularly as a result of this development of professional standards for evaluation). 


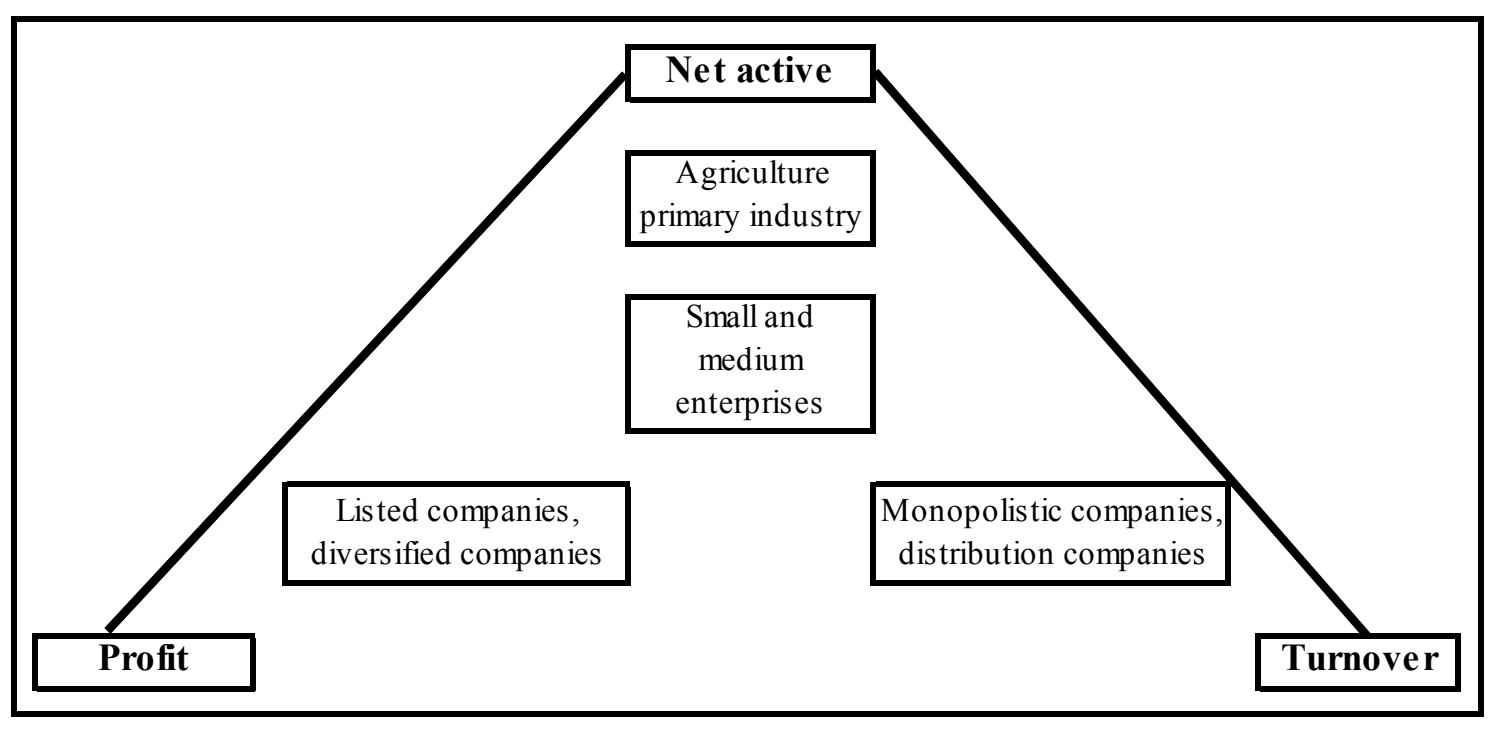

Source: Brilman and Gautier, 1976.

Figure 1. The evaluation of three main points of a company.

Different applications promote enterprise evaluation and in case of goodwill also based on the three approaches to value (assets or expenses, income, and comparison).

\subsubsection{Adjustments in Evaluating Specific Business}

The main adjustments in the evaluation of enterprise

There are different opinions about the discounts and premiums correct values from methods of assessment, but rather from disagreements over which the base value in logically, corrections must be applied.

Improving methods to assess the heritage most experts agree that discounts applied in the main business are:

a) The discount for lack of control;

b) The discount for lack of liquidity;

Other discounts apply in the enterprise are:

a) discount for key people;

b) blockage discount;

c) the discount for lack of access to reliable information;

d) the discount for non-voting shares.

\subsubsection{Adjusting Control}

The investor who wants a controlling stake in a company pays a higher price per share to a minority investor. To control the stakes of a company provides a range of following powers: the declaration and payment of dividends, the appointment and establishment of control and how remuneration of management, policy setting and changing the strategic lines of a business, sale of assets, making operations, acquisition and merger, liquidation, dissolution, recapitalization or splitting the company, company listing on the stock exchange, etc..

Among the factors that affect a firm control note:

a) distribution of business ownership;

b) the majority of statutory situation, packet size blocking important decisions;

c) articles of agreement and the status of the company;

An analysis carried out revealed that the U.S. economy size of control premium was between $27 \%$ and $45 \%$, value middle of this first for the 381 transactions sampled in 1996 was $27.3 \%$.

\subsubsection{Adjustment for Minority}

EVS 5 - standard valuation of the company defines discount for the minority (no control) as "an amount or percentage of the full value of an interest in the business that reflects the absence of some or all control rights." Specialists consider that the estimate is a minority based on three methods usual:

1) percentage discount method

2) Method comparison with minority stakes transactions

3) capitalized dividend adjustment method

Example: (Method discount percentage)

* The estimated capital of $100 \%$ is of $\$ 5,000,000$ monetary units and $\$ 500$ per share;

* The value of a minority stake of $10 \%$ of capital company will be $10 \%$ before adjustment $\times \$ 5,000,000=\$ 500,000$ also $\$ 500$ per share;

* Suppose the market price of shares in a company comparable was $\$ 800$ per share. Offer buying a majority stake in the firm to achieved at the price of $\$ 1,000$ per share. It follows, therefore, a minority discount of 20\%: (\$1000$\$ 800$ ) $/ 1000=20 \%$;

* Under these conditions the value of $10 \%$ minority stake undertaking will be assessed $\$ 500,000 \times(1-0.2)=\$ 400.000$, that an estimated $\$ 400 /$ action.

\subsubsection{Adjustments for Lack of Liquidity}

In the evaluation, liquidity, to emphasize means the ability to quickly convert the property into money, with a minimum and maximum cost certainty vis-à-vis the price to be obtained.

Quoted shares and debentures held can be sold quickly secondary markets in seconds, with a low-cost transaction at a price very close to that of the last operation that asset market. This creates a common basis for comparison 
accepted by investors to measure the liquidity of an investment.

Evaluators use two sources of information to estimate this discount:

a) comparison between closed transactions and shares in companies transactions with shares in companies quoted on the financial market;

b) comparisons of transactions with shares in companies before printed and after being listed.

Studies have statistically analyzed the sales of listed companies developed markets have shown that the size of the discount for lack of liquidity is inversely proportional to the size businesses. The discount usually ranges between $25 \%$ of the firms with a turnover of over 700 million USD and 50\% Small Business.

\section{Conclusion}

The alternative evaluation treatment, covered by national legislation allows revaluation of tangible assets at the end of the fiscal year for the presentation in the financial statements the fair value of fixed assets such as the results of reevaluation. The International Standard specifies that subsequently initial recognition; tangible assets must be evaluated at fair value at the evaluation moment reduced by adjustments for depreciation and amortization. Both kinds of regulations stipulate that revaluation must be made with sufficient regularity so as it does not exist major differences between the amount recorded in the financial statements and their fair value balance at the end of the fiscal year.

We can conclude the idea that because of this last national regulation, we adopted legislative changes which put us very much closer to international regulations on the matter and that professional reasoning can be applied in many cases without being limited to strictly follow the line without a specific alternative for intangible assets evaluation and tangible fixed assets.

\section{References}

[1] Bordalo, P.; Gennaioli, N.; Shleifer, A.; (2013), Salienceand Asset Prices, American Economic Review: Papers \& Proceedings, Year 2013, Vol. 103 (3): pp. 623-628, http://dx.doi.org/10.1257/aer.103.3.623.

[2] Brilman, J.; Gautier, A. (1976), Pratique de l'évaluation et de la négociation des entreprises, Paris, Hommes et Techiques.

[3] Chasan, E. (2009), Auditor "going concern" warnings seen peaking in '09. Reuters.

[4] Choi, J. S.; Nam, J. A. (2019), Does managerial discretion affect the value relevance of good will impairment information under IFRS? Korean evidence, Asia-Pacific Journal of Accounting \& Economics. Year 2020, Vol. 27, No. 1, 1-3, pp. 1-23, ISSN: 1608-1625 (Print), 2164-2257 (Online).

[5] Epstein, B. J.; Jermakowicz, E. K. (2007), Interpretation and Application of International Financial Reporting Standards. John Wiley \& Sons, ISBN 9780471798231.

[6] Hagendorf, K. (2009), Labour Values and the Theory of the Firm. Part I: The Competitive Firm, Paris: "EURODOS".

[7] Gleibner, W.; Ernst, D.; (2019); Company valuation as result of risk analysis: replication approach as an alternative to the CAP, Business Valuation OIV Journal, Spring 2019, Volume 1, Issue, pp. 3-18.

[8] Kieso, D. E.; Weygandt, J. J.; Warfield, T. D. (2007), Intermediate Accounting, $12^{\text {th }}$ Ed., ISBN 978-0-471-44896-9.

[9] Kimmel, P. D.; Weygandt, J. J.; DeFranco, A. L. (2008), Hospitality Financial Accounting, $2^{\text {nd }}$ ed., ISBN 978-0-47008360-4.

[10] Miciula, I.; Kadlubek, M.; Stepien, P.; Gautier, A. (1976), Modern Methods of Business Valuation-Case Study and New Concepts, Sustainability MDPI, Year 2020, Vol. 12, No. 2699, pp. 1-22.

[11] Pratt, J. W.; Kulsrud, W. N. (2010), Federal Taxation, ch. 9. Ed., ISBN 978-1424069866.

[12] Shell, E. R. (2009), Cheap: The High Cost of Discount Culture, New York: Penguin Press, ISBN 9781594202155.

[13] Stickney, C. P.; Weil, R. L.; Schipper, K.. (2012), Financial Accounting: An Introduction to Concepts, Methods and Uses, Chapter 9, ISBN 13: 978-0-324-65114-0, ISBN-10: 0-32465114-7.

[14] Visconti, R. M.; (2019), The Valuation of Intangible Assets: An Introduction. SSRN Papers: https://ssrn.com/abstract=3413524,Posted: 6Jul2019, 33pages.

[15] Williams, J. R.; Haka, S. F.; Bettner, M. S.; Carcello, J. V. (2006), Financial Accounting, $12^{\text {th }}$ ed., Mass: McGrawHill/Irwin, ISBN0072884673.

[16] Willis, E.; Hoffman, W. H. Jr., (2009), South-Western Federal Taxation, 2009 ed. ISBN 978-0-324-66208-5.

[17] Wolk, H., I.; Dodd, J. L. (2016), Accounting Theory: Conceptual Issues in a Political and Economic Environment, $6^{\text {th }}$ ed. South-Western, ISBN0-324-18623-1.

[18] Woodford, W.; Wilson, V.; Freeman, S.; Freeman, J. (2008), Accounting: A Practical Approach, $2^{\text {nd }}$ ed., Pearson Education, ISBN 978-0-409-32357-3.

[19] Demir, E.; Yeniceri, H.; Marufoglu, A. (2016), Vat Stoppage Applied In Survey, Plans And Projects, Audit And Consulting, And Simular Services For Businesses, And Problems Caused By It, Eurasian Academy of Sciences Eurasian Business \& Economics Journal, Year 2016, Vol. S1, pp. 409-418, http://dx.doi.org/10.17740/eas.econ.2016-MSEMP-36. 